\title{
Developing of thin chromium-free multifunctional treatments on hot dip galvanized steel: strategy, implementation and experience
}

\author{
M. Fleischanderl, G. Reiter, S. Marion, E. Stögmüller, G. Fafilek
}

Since the use of hexavalent chromium in automotive and electronic equipment is largely prohibited, many different hexavalent chromium free conversion layers have been developed. In this work, different Crfree phosphate and polycarboxylate based conversion coatings were characterized (with electron microscopy

and other surface analytical methods) for the usage of a multifunctional property layer for hot dip

galvanised steel strips. The different corrosion resistance of such conversion coatings on ZM [1] (ZnAlMg) and $Z(Z n)$ will be another topic of this paper [2]. The corrosion protection properties of these phosphate based conversion coatings on $Z$ and $Z M$ were characterized in a standardized salt spray test. Finally the conversion layers and the barrier protection effect on Cr-free treated zinc and zinc magnesium was investigated by cyclovoltammetry.

Keywords: Cr-free passivation, Cr-free conversion layer, corrosion mechanisms, zinc-aluminium-magnesium, cyclovoltammetry, temporary corrosion protection

\section{INTRODUCTION}

European ordinances, the so-called RoHS [3] and the Directive on End-of-Life Vehicles [4], are of particular interest for our customers. They prohibit the application of chromium-(VI)containing compounds for passivation and pre-treatment of metallic surfaces in the automotive and household-appliance industries beginning in June 2006 and July 2007, respectively. $\mathrm{Cr}(\mathrm{VI})$ - containing products have not only a very high performance and fulfil in this way the requirements for many applications, but they are also very cost effective. It was not easy to develop an alternative Cr-free technology and fulfil all requirements of the customers [5]. Particularly the guideline regarding the restriction of hazardous materials poses a big challenge to the producers of household, automotive and building appliances and their suppliers [6]. Since 1990 voestalpine
Stahl GmbH concerned itself with the topic of chromate-free and chromium-free coatings and pre-treatment methods. This involvement has put the company in the position of having more than twenty years of successful experience in the area of chromiumfree production of strip-coated material and ten years of successful experience in passivation of hot dip galvanized material [7]. In Figure 1 the history of developing Cr-free technologies is presented. This expertise is put into every-day practice in cooperation with chemical supply partners in various projects, in particular with Henkel and BASF. Based on several theses works and in cooperation with Henkel and CEST (Centre of Electrochemical Surface Technology) in 2008 we have been successful in implementing a completely chromium-free conversion treatment for passivating hot-dipgalvanised steel strip (include zinc magnesium alloys) for

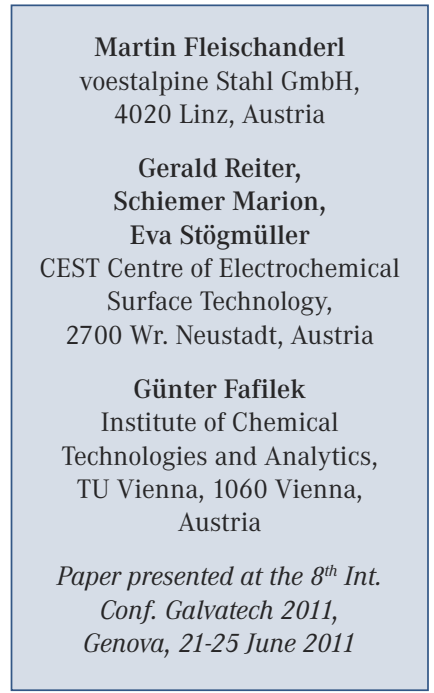

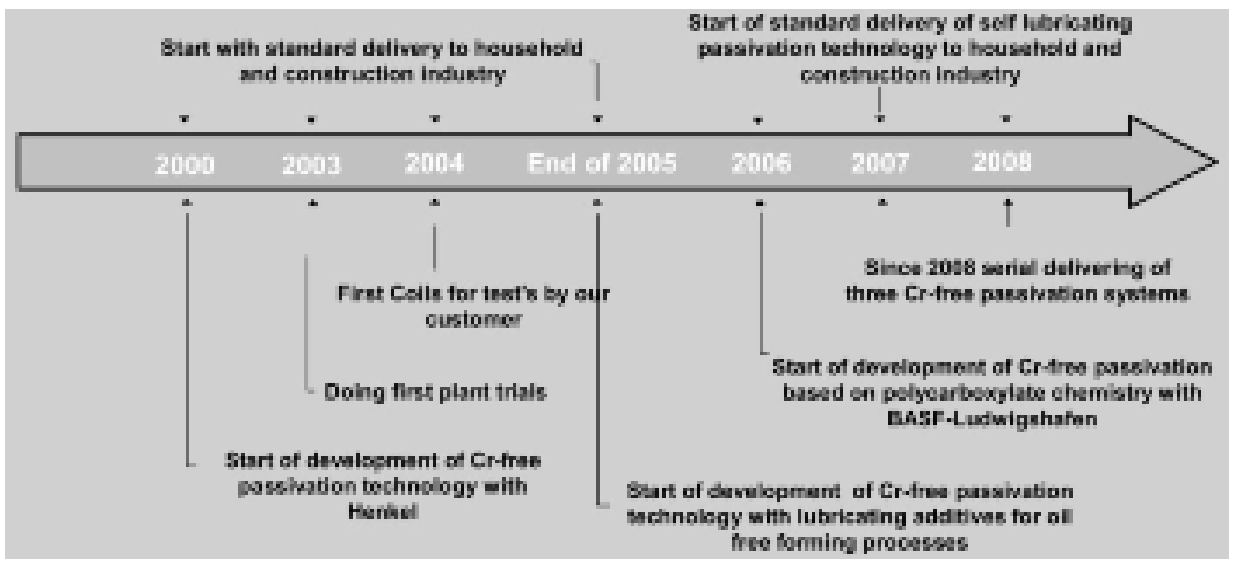

FIG. 1 History of developing Cr-free passivation systems by voestalpine white rust area. Storia dello sviluppo di sistemi di passivazione esenti da $\mathrm{Cr}$ da parte di voestalpine area ruggine bianca. 


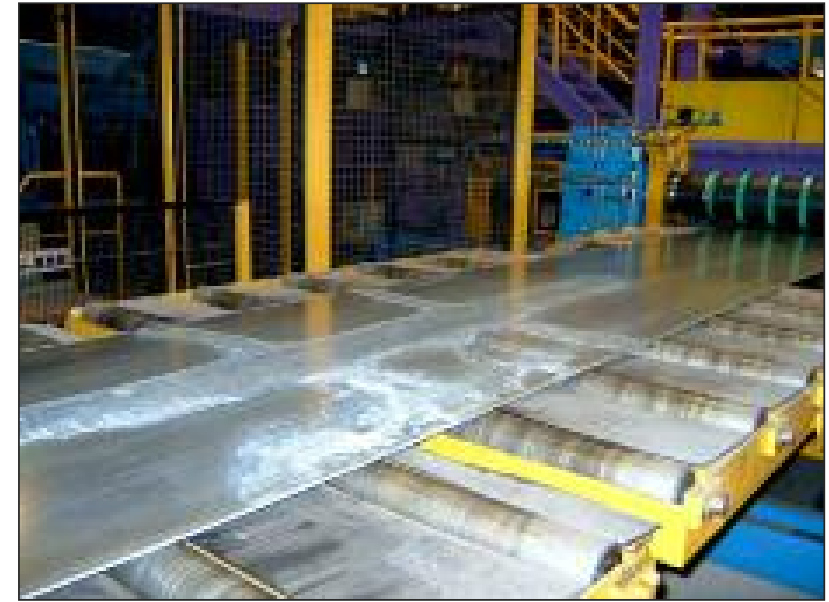

FIG. 2 Picture of white rust formation after long transportation and storage time.

Immagine della formazione di ruggine bianca dopo un lungo periodo di trasporto e stoccaggio.

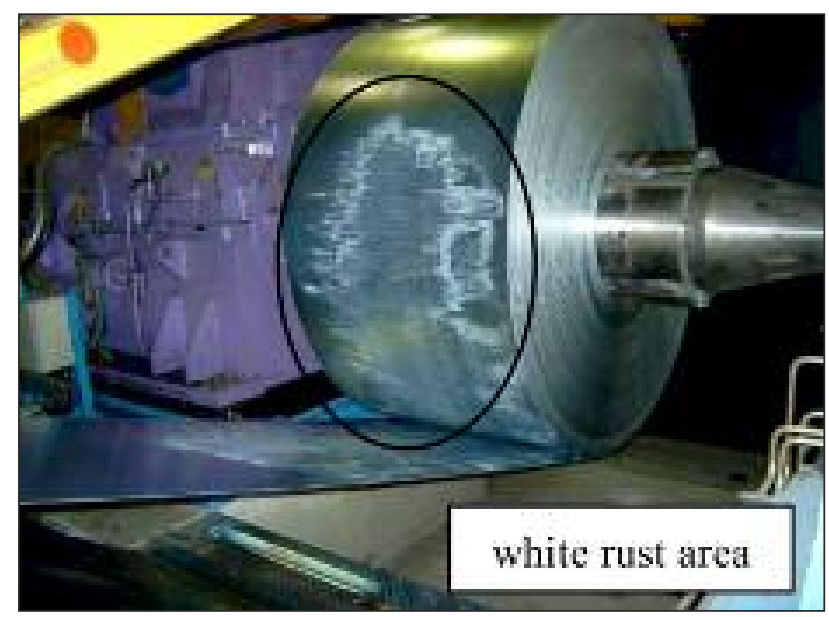

FIG. 3 The same HDG coil as shown in Fig. 2, before down coiling.

Lo stesso coil HDG di Fig. 2, prima del "down coiling".

temporary corrosion protection [Fig. 4 to 8]. In cooperation with BASF we developed a Cr-free and Fluoride-free passivation system. This system is based on polycarboxylate-chemistry [Fig. 9,10,11]

In this work, different conversion coatings based on Cr-free phosphate- and polycarboxylate-chemistry on Z and ZM were characterised with electron microscopy and other surface analytical methods. Specially, time studies of corrosion behaviour of phosphate based conversion coatings on $\mathrm{Z}$ and $\mathrm{ZM}$ in salt spray test on cross section prepared samples are shown.

Multifunctional property layer means the very positive influence on the surface properties of galvanized steel sheets in many aspects: excellent corrosion protection, good paintability and paint adhesion when used as pre-treatment, good weldability, easy and cheap application by spray and squeegee rolls and low chemical cost. Temporary corrosion protection is absolutely necessary. In Figure 2 and Figure 3 pictures of areas with white rust on hot dip galvanised steel coils on a slitting line are shown. The white rust material was stored a long time in an unprotected humid atmosphere.

The affected material is in most cases not useable in $\mathrm{Cu}-$ stomer processes any more. In respect to barrier properties of conversion coatings resistance to salt spray test and resistance to alkaline solutions are important. Later is important in case of forming with lubricants or emulsions that are highly alkaline and which decrease the friction coefficient of the chromium-free passivated surface [7]. One special solution to deal with this problem is to apply a thin oil-film on the passivated surface. An alternative approach to solve this problem was the development of conversion layers with self lubricating surface properties by adding waxes in order to obtain oil-free forming [8]. SEM investigations and the corrosions protection of this conversion layer is shown in Fig. 7,8 and Fig. 15.

The formation of corrosion products of treated $\mathrm{Z}$ and ZM, was tested in a salt spray chamber. After each exposure for a certain time, SEM- and EDX-analysis of cross section were made [9], [10].

The performance of the new treatments should be comparable to that of the $\mathrm{Cr}(\mathrm{VI})$-containing layers. The performance of the $\mathrm{Cr}(\mathrm{VI})$-containing layers rises with the coating (layer) weight (the Cr-content was measured with a X-ray fluorescence spectrometer). Results on hot dip zinc coated samples with $\mathrm{Cr}(\mathrm{VI})$-passivation treatment (coating weight about $15 \mathrm{mg}$ $\mathrm{Cr} / \mathrm{m}^{2}$ ) were used to set up the requirements list. Lab tests used to check these properties are summarised in Table I. Additional requirements or other properties like adhesive joining, weldability, formability and so on are not listed. They are depending too much on the final application demands and on special requirements from customers.

\section{EXPERIMENTAL}

Sample Preparation

To study the relationship between conversion layer thickness and properties of passivated hot dip galvanized steel sheets samples with different conversion layer thicknesses were prepared in the lab.

Samples for other investigations were taken from industrially produced passivated hot dip galvanized steel strips. At the laboratory the application of the passivation solution was done by a coating process. For these samples, hot dip galvanised steel sheets (size $400 * 210 \mathrm{~mm}$ ) were cleaned by transferring them into an alkaline washing machine. After this procedure the samples were treated with different types of passivation solutions by means of a coating knife (Spiral Rakel). The wet samples were dried by a hot air dryer. For analytical and electrochemical investigations the samples

\begin{tabular}{|ccc|}
\multicolumn{2}{|c|}{ Test method } & Requirements \\
\hline Alternating Humidity Test & DIN 500017 KFW & $<5 \%$ WR (white rust) after 20 cycles \\
\hline Salt Spray Test & DIN 50021SS & $<5 \%$ WR* after $24 \mathrm{hrs}$ \\
*...WR (white rust) & & \\
\hline
\end{tabular}

TAB. I Test methods and requirements on passivation layers (Z, ZM).

Metodi di prova e requisiti per gli strati di passivazione (Z, ZM). 
were cut to small sizes $(10 * 10 \mathrm{~mm})$. For testing the corrosion protection properties the sample size was $100 * 160 \mathrm{~mm}$. Two different metallic coatings conventional zinc coating (Z) and a $\mathrm{Zn}-\mathrm{Mg}$-Al alloy coating (ZM) consisting of Zn with $2 \% \mathrm{Mg}$ and $2 \% \mathrm{Al}$ provided by voestalpine were used. All samples were not skin passed.

\section{Methods}

SEM and EDX were measured with a 1540 XB from ZEISS. The electrochemical investigations were made with a solartron 1285 potentiostat and a cell equipment from EG\&G. A very important and a very difficult factor for comparing investigations is to determine the conversion layer thickness (coating weight) exactly and fast. Coating weight was measured with XRF-device, called Thermo Niton XL3t-900. The white rust (WR) behaviour was examined by means of salt-water spray test chambers (in accordance with DIN 50021SS) and cyclic condensed water test chambers (in accordance with DIN 50017KFW).

RESULTS AND DISCUSSION

Structure of $\mathrm{Cr}$-free passivation layer

Fig 4, 7, 9, 12 show the schematic structure of the different pas-

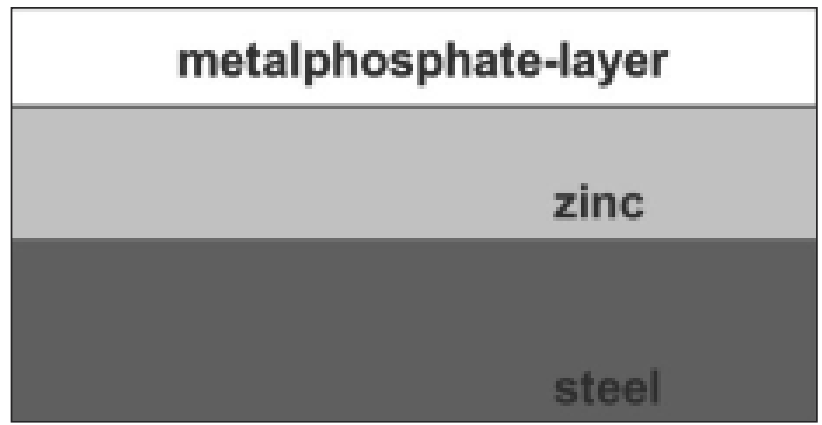

FIG. 4 Schematic drawing of the composition of phosphate-based passivation system.

Schema della composizione del sistema di passivazione a base di fosfati.

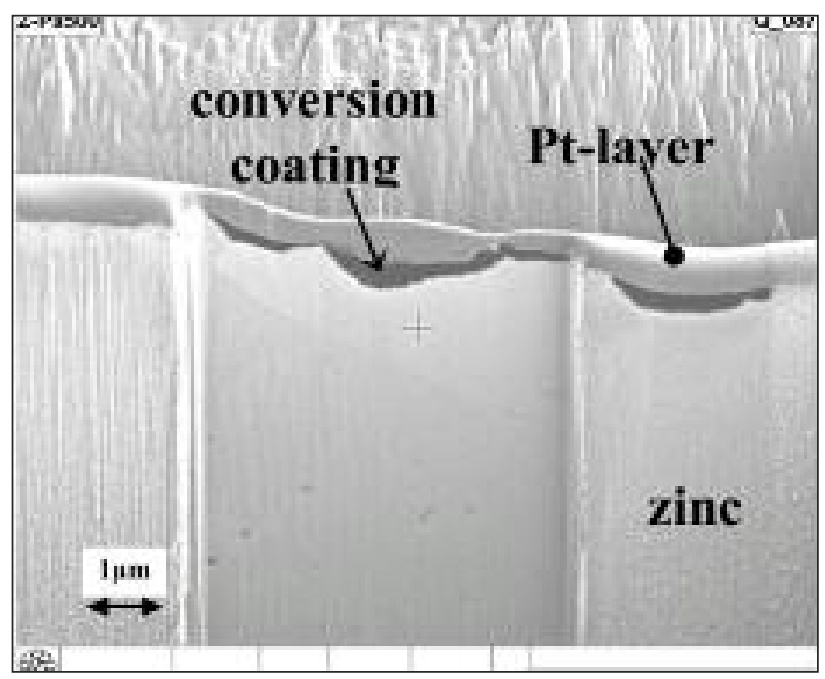

FIG. 5 Cross section view through phosphate based conversion layer; prepared by FIB (Focused Ion Beam).

Vista trasversale dello strato di conversione a base $d i$ fosfati; preparato mediante Fascio di ioni focalizzati FIB.

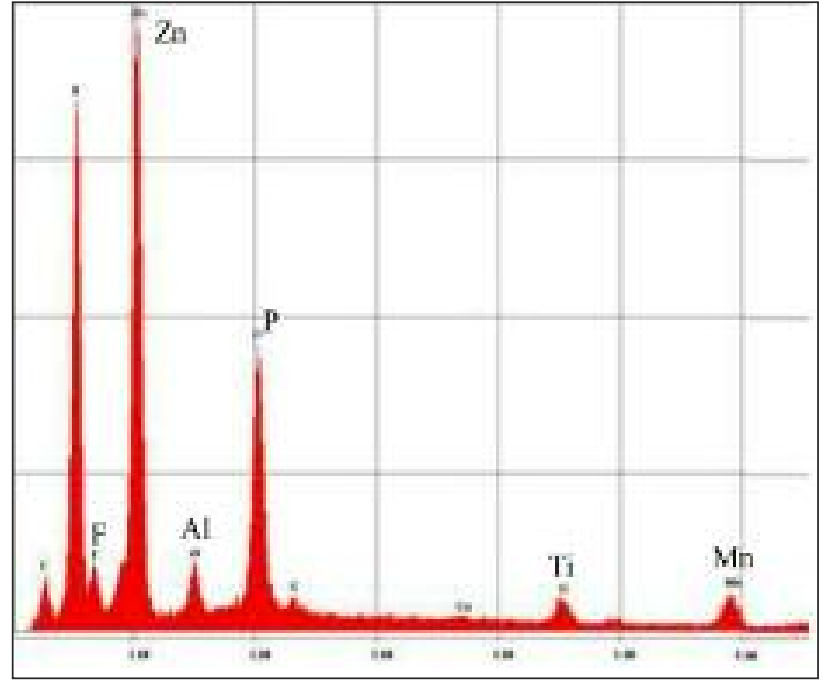

FIG. 6 EDX analysis of the conversion coating at cross section.

Analisi EDX della sezione trasversale dello strato di conversione.

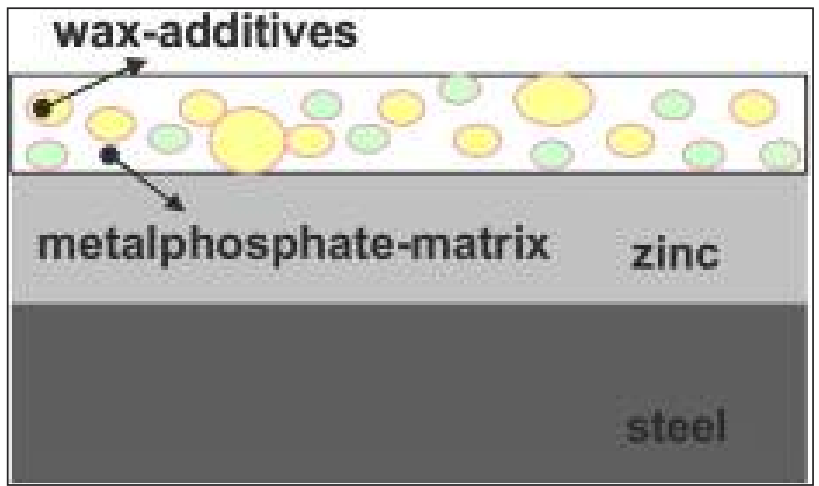

FIG. 7 Schematic drawing of the composition of phosphate-based and wax added passivation system.

Schema della composizione dei sistema di passivazione a base di fosfati e con aggiunta di cera.

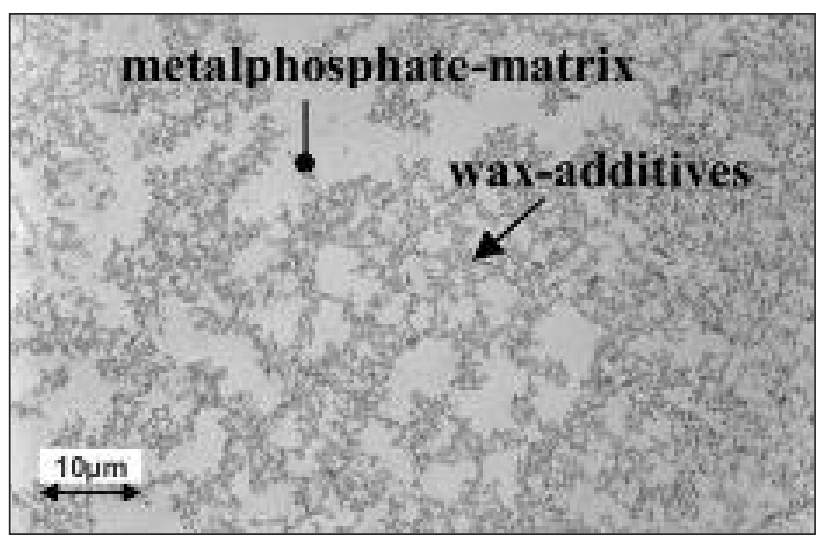

FIG. 8 SEM micrograph of the surface of passivation layer with lubrication properties. Source [11].

Micrografia SEM dello strato di superficie di passivazione con caratteristiche di lubrificazione. Fonte [11]. 


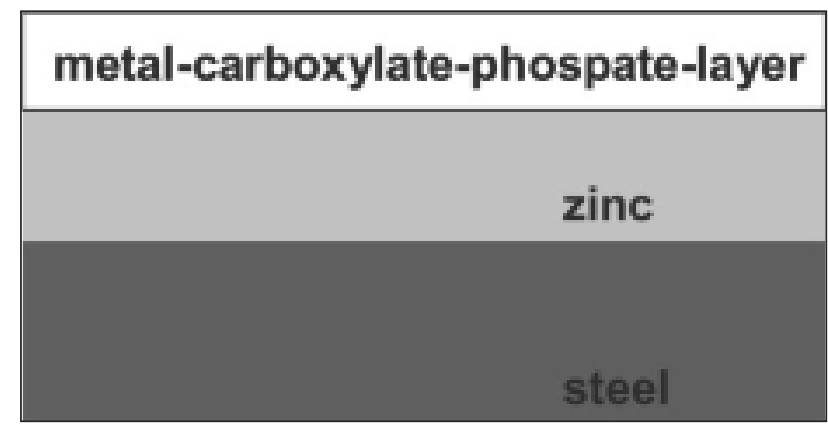

FIG. 9 Schematic drawing of the composition of polycarboxylate-based passivation system.

Schema della composizione del sistema di passivazione a base di policarbossilati.

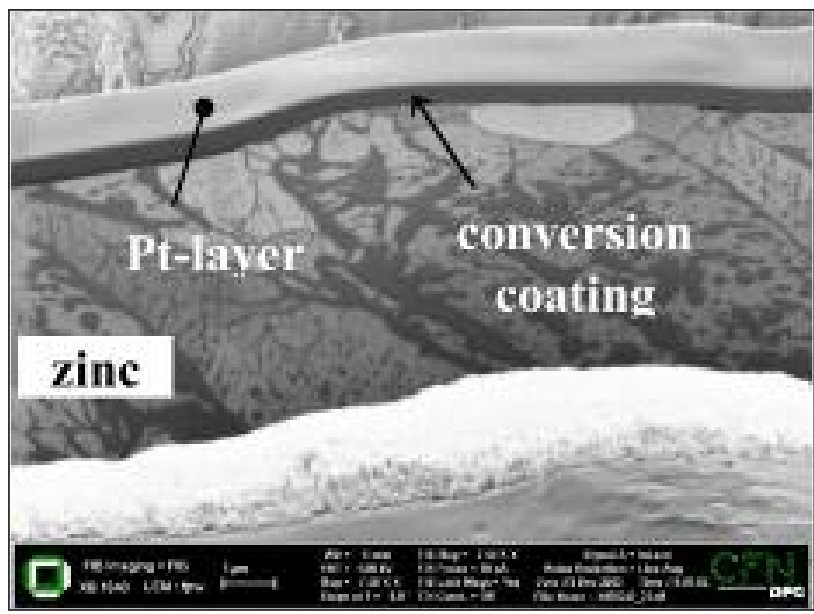

FIG. 10 Cross section view through polycarboxylate-based conversion layer; prepared by FIB.

Vista trasversale dello strato di conversion a base di policarbossilati; preparato mediante Fascio di ioni focalizzati - FIB.

sivation layers on the substrates $\mathrm{Z}$ and ZM. The corresponding micrographs (Fig. 5, 8, 10,13) display the structures of the conversion coatings on the various substrates.

The corresponding layer analyses (EDX) are shown in Figures 6, 11 and 14. The system based on metal phosphates consists of titanium, manganese and zinc phosphates (Fig. 6). The aluminum signal comes from the zinc coating. The fluorine comes from the titanium salt. Sulfur and calcium are from impurities. The phosphate based and wax added (self lubricate) passivation layer also consists of a growing organic component besides the metal phosphates. The structure of the metal phosphate or polycarboxylate based conversion layers are inorganic/organic and amorphous. The typical coating weights are 0.4 up to $1.2 \mathrm{~g} / \mathrm{m}^{2}[0.2$ to $0.6 \mu \mathrm{m}]$.

\section{Corrosion}

To investigate corrosion protection properties, normalised accelerated tests, i.e. salt spray test, humidity test, stack test and so on were used. Fig. 15 describes the evolution of white rust during salt spray testing at passivated $\mathrm{Z}$ and $\mathrm{ZM}$ samples. The reference coating weight (dry film) for these samples is 22 $\pm 5 \mathrm{mg} \mathrm{Ti} / \mathrm{m}^{2}$ for phosphate-based and $35 \pm 5 \mathrm{mg} \mathrm{P} / \mathrm{m}^{2}$ for polycarboxylate-based samples.

The phosphate and phosphate and waxes based passivation show the best corrosion resistance for both metallic coating

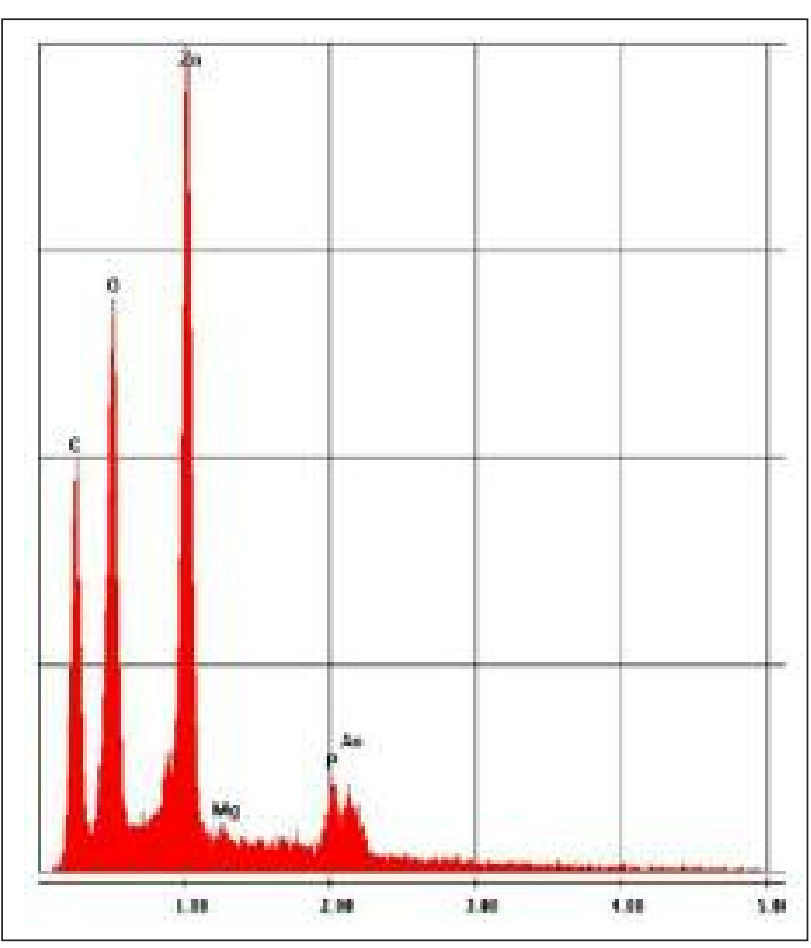

FIG. 11 EDX of the conversion coating at the cross section.

Analisi EDX della sezione trasversale dello strato di conversione.

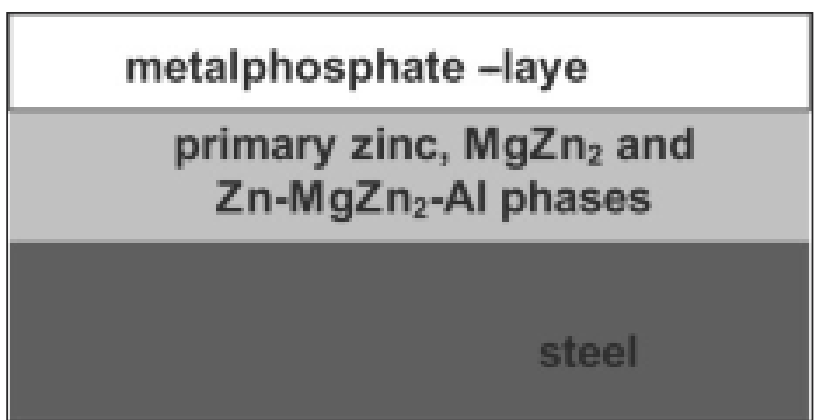

FIG. 12 Schematic drawing of the composition of phosphate-based passivation system on ZM surface.

Schema della composizione del sistema di passivazione a base di fosfati su superficie ZM.

types (Z, ZM). Generally in salt spray test the corrosion protection of ZM alloys are much higher than $Z$ [9, 12]. This property is also found for the passivated surface. Passivated Z-coatings corroded faster than passivated ZM-coatings. The excellent results with Cr-free systems for ZM surface in comparison to $\mathrm{Z}$ surfaces is not fully understood. In addition, the influence of passivation layer thickness on the rate of white rust formation was investigated in the salt spray test.

For this purpose $\mathrm{Z}$ and ZM samples were lab coated. To get different dry film layer thickness constant wet film thickness but different chemical concentrations were used.

As shown in Figure 16 and Fig 17 the stability against white rust on $\mathrm{Z}$ and ZM rises with increasing layer thickness of the conversion layer. This was also the case in respect to corrosion protection against red rust formation in salt spray test for Z. But the opposite trend was found for ZM (Table II)

This observation may be due to localized white rust formation caused by higher conversion coating thickness. As shown in Fi- 


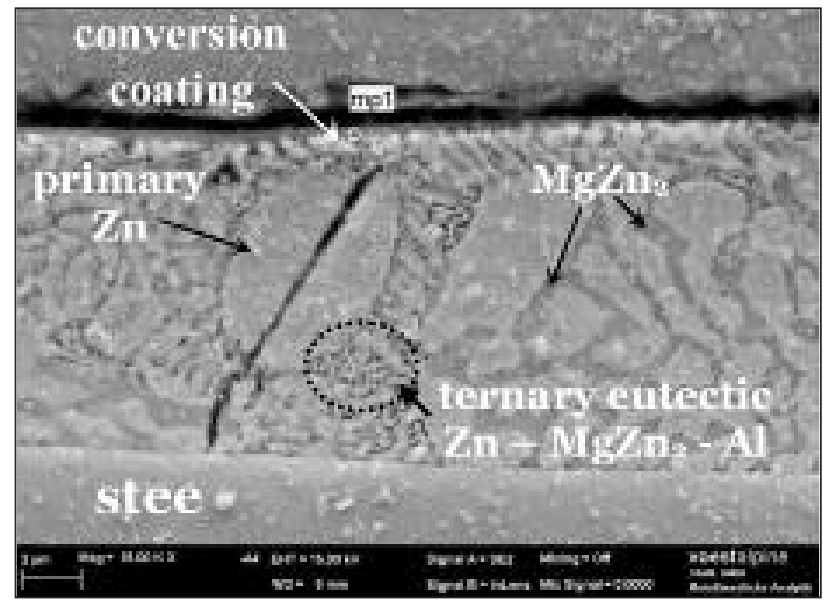

FIG. 13 Cross section through phosphate-based conversions layer; prepared by FIB.

Sezione trasversale dello strato di conversione a base di fosfati; preparato mediante Fascio di ioni focalizzati FIB.

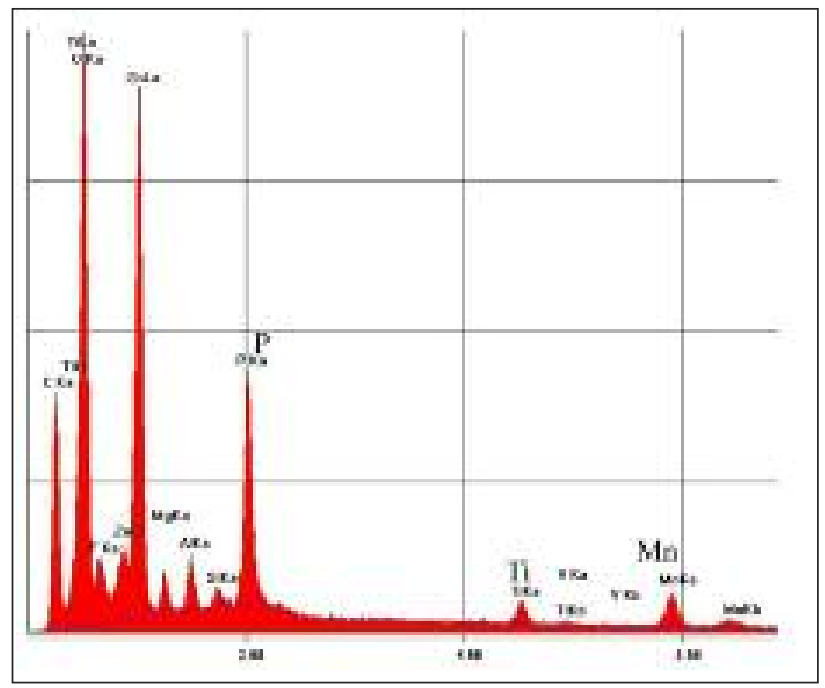

FIG. 14 EDX of the conversion coating at cross section (mp1).

Analisi EDX della sezione trasversale dello strato di conversione (mp1).



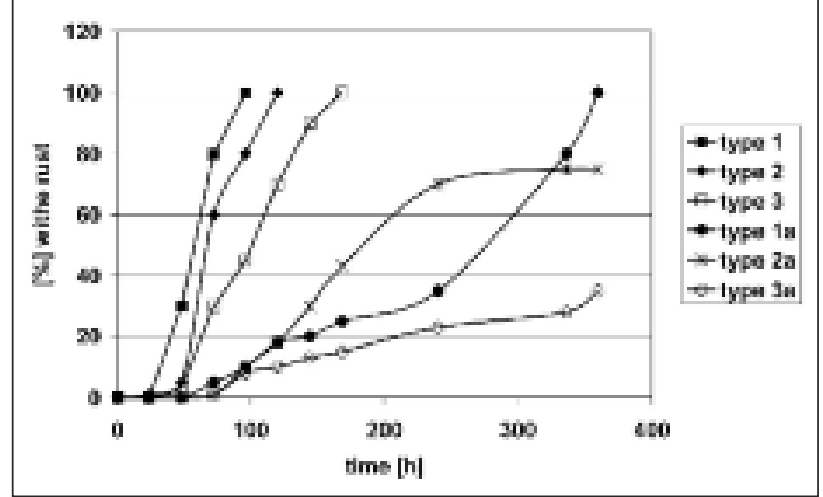

FIG. 15 Evolution of white rust on samples from the HDGline with different $\mathrm{Cr}$-free passivation solutions in salt spray test. Type 1: phosphate based passivation on Z, Type 2: polycarboxylate based passivation on Z, Type 3: phosphate and waxes based passivation on Z, Type 1a: phosphate based passivation on ZM, Type 2a: polycarboxylate based passivation on ZM, Type 3a: phosphate and waxes based passivation on ZM.

Evoluzione della ruggine bianca su provini dalla linea HDG con diverse soluzioni di passivazione esente da $\mathrm{Cr}$ in prove in nebbia salina. Tipo 1: passivazione a base di fosfati su Z, Tipo 2: passivazione a base di policarbossilati su Z, Tipo 3: passivazione a base di fosfati e cere su Z, Tipo 1a: passivazione a base di fosfati su ZM, Tipo 2a: passivazione a base di policarbossilati su ZM, Tipo 3a: passivazione a base di fosfati e cere su ZM.

gure 17, the corrosion products (white rust) on ZM samples of lower layer thickness are more extensively allocated than on samples of higher layer coatings.

Higher layer thickness basically leads to higher stability of the conversion layer. One possible reason is a declining number of defects (pores, anodic areas). This hypothesis was confirmed by electrochemical investigations (Fig. 20). Therefore corrosion attack is concentrated on few localized anodes.

To characterize the state of conversion layer and coatings ( $Z$, ZM), cross sections of salt spray test exposed samples were prepared and then analyzed by scanning electron microscope. After first white rust that is actually visible on the surface, a cross-

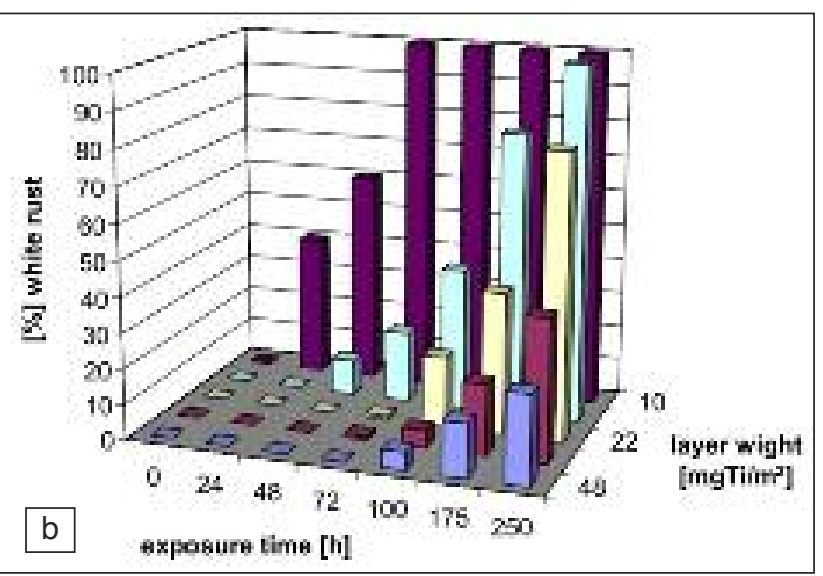

Fig. 16 Evolution of white rust on samples treated with different concentrations of phosphate based passivations in laboratory in salt spray test. a: Z material, b: ZM material.

Evoluzione della ruggine bianca su provini trattati con diverse concentrazioni di passivazione a base di fosfati in prove di laboratorio con nebbia salina. a: materiale $Z$, b: materiale ZM 


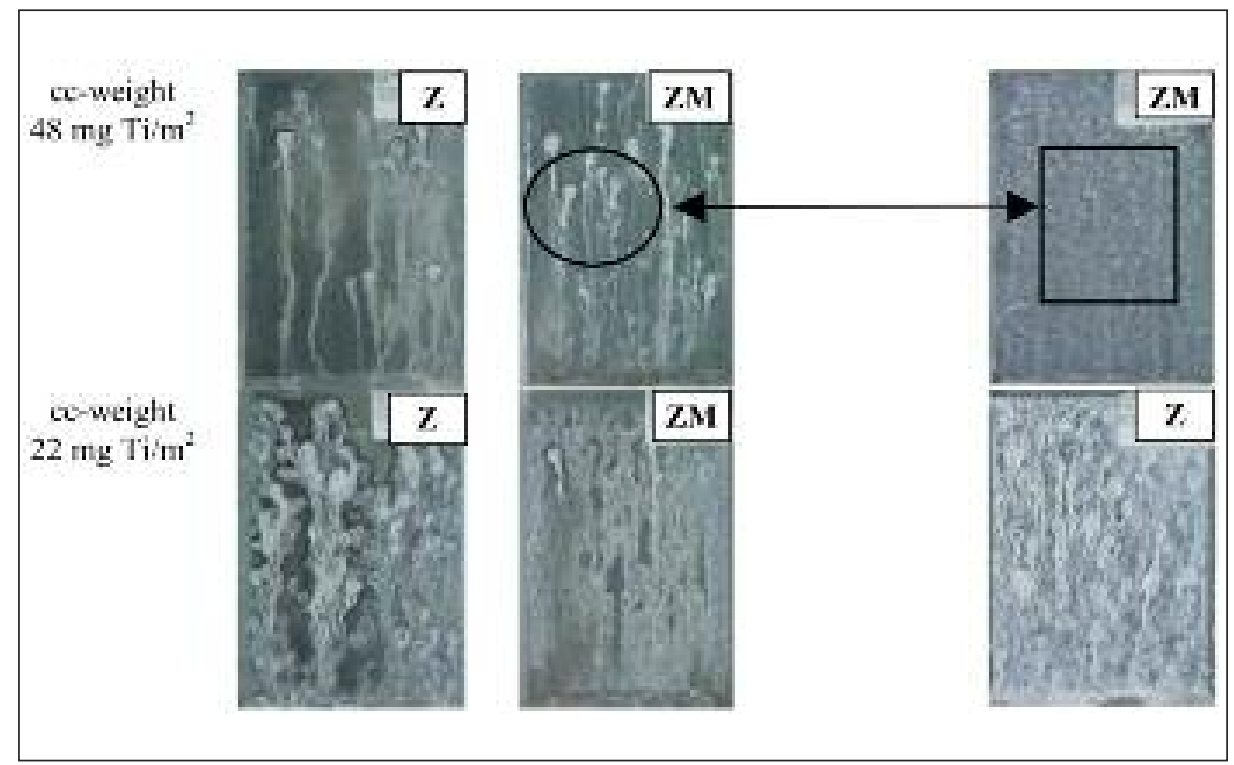

FIG. 17

Evolution of white rust on samples with different conversion coating (cc) weights (phosphate based) at different times in salt spray test, (a) $Z 100 \mathrm{~g} / \mathrm{m}^{2}$ material, $72 \mathrm{hrs}$, (b) $Z M 120 \mathrm{~g} / \mathrm{m}^{2}$ material 300 hrs, (c) Z 275 and ZM 120 material without any conversion coating, 300hrs.

Evoluzione della ruggine bianca su provini con diversi pesi dei rivestimenti di conversione (cc) - (a base di fosfati) per diverse durate di prove in nebbia salina. (a) materiale $Z 100 \mathrm{~g} / \mathrm{m}^{2}, 72 \mathrm{~h}$, (b) materiale ZM $120 \mathrm{~g} / \mathrm{m}^{2} 300 \mathrm{~h}$, (c) materiale $Z 275$ e ZM 120 senza alcun rivestimento di conversione, $300 \mathrm{~h}$.

\begin{tabular}{ccc|} 
cc weight & \multicolumn{2}{c}{$\begin{array}{c}\text { exposure time to red rust[h] } \\
\text { Type of sample }\end{array}$} \\
& HDG $100 \mathrm{~g} / \mathrm{m}^{2}$ & $\mathrm{ZM} 120 \mathrm{~g} / \mathrm{m}^{2}$ \\
48 & 250 & 1000 \\
28 & 175 & 1100 \\
22 & 175 & $>1100$ \\
15 & 100 & $>1600$ \\
10 & 100 & $>1600$ \\
0 & 70 & $>1600$ \\
\hline
\end{tabular}

TAB. II Time of corrosion protection in salt spray testing.

Durata della protezione dalla corrosione in prove in nebbia salina.

\begin{tabular}{|ccccc|}
\hline EDX & $\begin{array}{c}\text { Mg } \\
\text { [wt\%] }\end{array}$ & $\begin{array}{c}0 \\
\text { [wt\%] }\end{array}$ & $\begin{array}{c}\text { Al } \\
\text { [wt\%] }\end{array}$ & $\begin{array}{c}\text { Zn } \\
\text { [wt\%] }\end{array}$ \\
\hline M2 & 7,2 & 3,3 & 2,2 & 87,2 \\
M3 & 2,6 & 10,6 & 1,4 & 85,4 \\
M4 & 1,6 & 15,6 & 1,3 & 81,5 \\
M5 & 2,8 & 25,5 & 0,8 & 70,9 \\
\hline
\end{tabular}

TAB. III Concentration of elements in corrosion products of treated ZM-surface

Concentrazione degli elementi nei prodotti di corrosione di una superficie ZM trattata.

section through corroded areas was prepared (Fig. 18). From cross sections it can be seen that the conversion layer in the dark area is still intact on both substrates (Fig. 18, M1). Even in white rust area of the $\mathrm{Z}$ surface the conversion layer components can be detected by using the EDX analysis (Fig. 18, M2). The corrosion products of passivated Z-surface can be divided into light and dark areas (Fig. 18, M3 and M4). Whereas the dark area shows only a zinc-and oxygen signal in the EDX spectrum (Fig. 18, M4), an additional phosphorus and chlorine signal was detected in the light area. Phosphate from conversion layer forms on pure zinc coatings zinc phosphate precipitates during corrosion. This phenomenon has not yet been observed in the case of ZM.
As can be seen from the cross section in Figure 18, the conversion layer of the ZM substrate has not yet been attacked in the intermediate region. In the area of white rust, however, about 2 $\mu \mathrm{m}$ thick corrosion products have been formed on top of the metallic ZM layer (Fig. 18, M5). At that stage the conversion layer cannot be detected anymore. From this shot it can be seen clearly that - despite the conversion layer - the $\mathrm{MgZn}_{2}$ phase has been resolved selectively at the beginning of the corrosion. To study the role of magnesium, a number of EDX spectra starting from a $\mathrm{MgZn}_{2}$ phase have been absorbed up to the corrosion products (Fig. 18, M2-M5), whereby measurement 2 (M2) is located in the metallic $\mathrm{MgZn}_{2}$ phase, M3 and M4 are situated in the corroded $\mathrm{MgZn}_{2}$ phase and M5 can be found in the corrosion products. The results of the quantification of these measuring points are shown in Table III.

The mass fraction of oxygen increases steadily from M2 to M5. After $650 \mathrm{~h}$ of exposure in the salt spray test the ZM coating is corroded completely. However, the thickness of the corroded layer is very different: whereas the corrosion products in the dark area have a thickness of about $10 \mu \mathrm{m}$, the thickness of the corrosion products in the white area may be of up to $100 \mu \mathrm{m}$ or even more.

Electrochemical investigations of passivated surface Determination of free zinc surface with cyclovoltammetry As described in [13] the free zinc-surface of a chemically passivated Z100 and ZM120 sample were determined by cyclic voltammetry. According to [14] for cyclic voltammogram the maximum anodic current density (Imax) in the potential range of zinc dissolution is a good indicator of the persistence of a chemically passivated surface. In addition, at repeated cyclizing the time course of the Imax can deliver an additional parameter for the persistence of the conversion layers. From Figure 19 it can be seen that with neutral electrolytes ( $\mathrm{pH} 7$ borate buffer) the conversion layer on the $\mathrm{Z}$ surface has lower current densities (less pores and cracks) in cyclovoltammetric measurement than on the ZM-surface. When changing the electrolytes to alkaline $\mathrm{pH}$-values ( $\mathrm{pH} 9$ ) a reversal of the Imax relations was shown. At this pH-value the conversion layer on ZM has now the lower current densities.

If Imax is plotted as a function of the cycle iterations, it will be achieved faster to get higher Imax values with thinner conversion layer thicknesses. I.e. the conversion layer is decomposed faster and therefore more zinc is exposed (Fig. 20). 
FIG. 18

SEM and EDX pictures of $Z$ and $Z M$ samples exposured in salt spray test, (a) column shows the investigations on $Z M$ 120 surfaces after 168 hrs exposured in salt spray test, (b) column on Z 100 after 48 hrs - $A$ Il samples are treated with phosphate based passivation solution in the laboratory.

Immagini SEM e EDX dei provini Z e ZM esposti nelle prove in nebbia salina, (a) la colonna mostra le rilevazioni sulle superfici ZM dopo $168 \mathrm{~h} \mathrm{di}$ esposizione nelle prove in nebbia salina, (b) colonna relativa a $Z M$ dopo $48 \mathrm{~h}$.

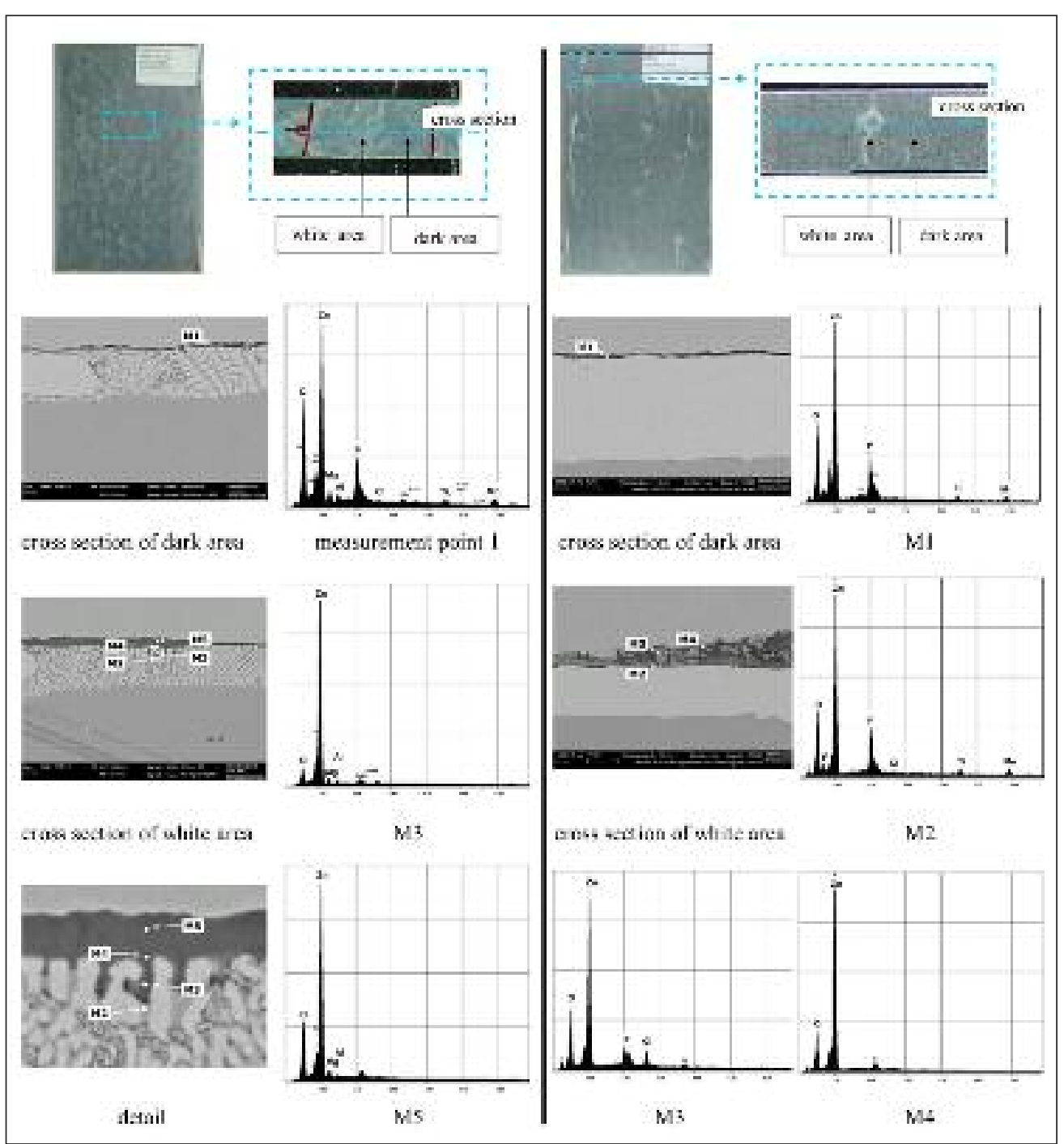

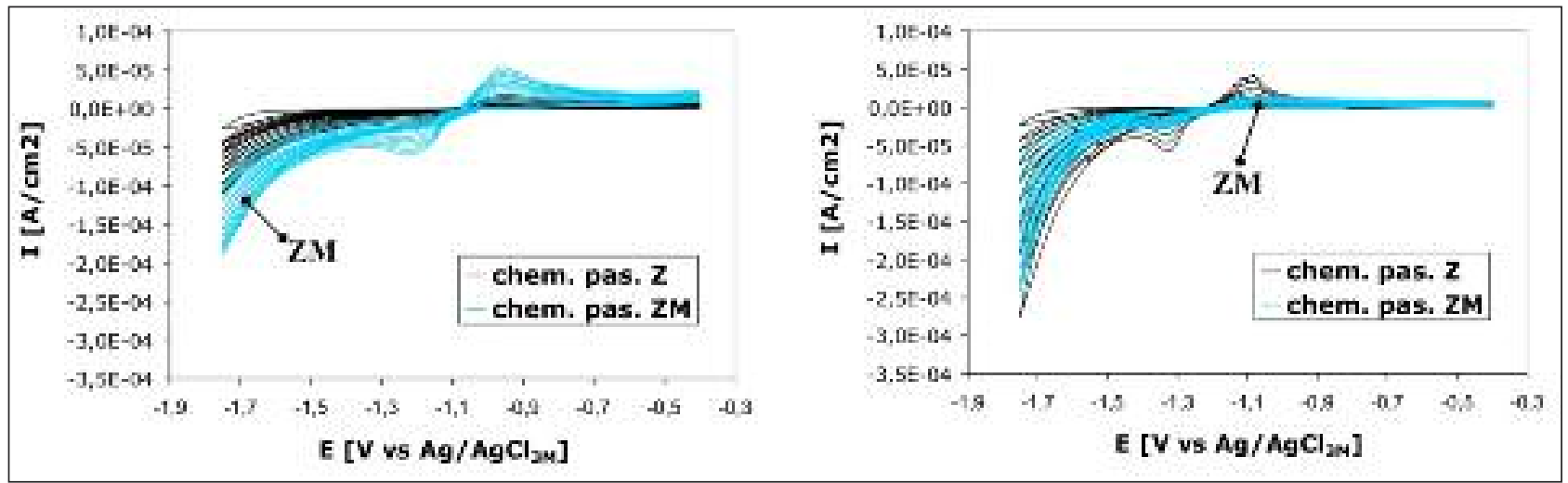

FIG. 9 Cyclovoltammetry on Z100 and ZM120 with phosphate based samples, $d U / d t=25 \mathrm{mV} / \mathrm{s}$, Electrolyte: (a) Borate buffer $\mathrm{pH}$ 7, (b) Borate buffer $\mathrm{pH} 9, \mathrm{~N}_{2}$ saturated.

Voltammetria ciclica sui provini Z100 e ZM120 a base di fosfati, $d U / d t=25 \mathrm{mV} / \mathrm{s}$, Elettrolita: (a) tampone borato a pH 7, (b) tampone borato a $\mathrm{pH} 9$, saturo di $\mathrm{N}_{2}$.

\section{CONCLUSION}

For storage and transport of galvanized steel strips it is necessary to chemically treat the surface to avoid formation of white rust. In the recent past passivation solutions based on $\mathrm{Cr}$ (VI) salts were used for this purpose. By the End-of-Life Vehicles regulation of the EU and the so-called RoHS regulation ma- nufacturers of passivation chemicals were pressured to look for alternatives. Therefore passivation solutions based on amorphous titanium, manganese and zinc phosphates have been developed. The synergetic effect of the new passivation treatments in combination with new ZM-coatings lead to excellent corrosion performance (especially white rust 


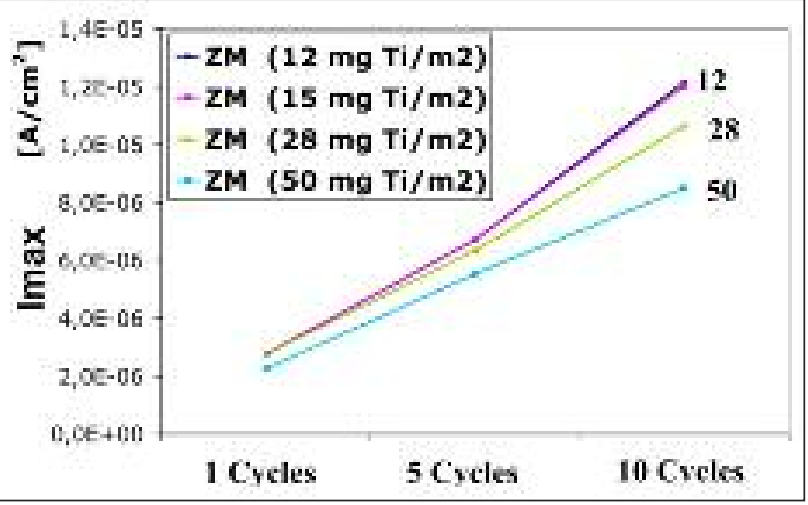

Fig. 20 Imax versus number of cycles, $d U / d t=25 \mathrm{mV} / \mathrm{s}$, Electrolyte: Borate buffer $\mathrm{pH} 9, \mathrm{~N}_{2}$ saturated, $d U / d t$ $=25 \mathrm{mV} / \mathrm{s}$.

Imax vs numero di cicli, $d U / d t=25 \mathrm{mV} / \mathrm{s}$, Elettrolita: tampone borato a $\mathrm{pH} 9$, saturo di $\mathrm{N}_{2}, d U / d t=25 \mathrm{mV} / \mathrm{s}$.

protection).This synergetic effect have not yet been fully understood. Whereas the first visible white rust on the chemically passivated zinc surfaces already occurs after approximately $30 \mathrm{~h}$ of exposure in the salt spray test, this takes about 70 hours on ZM surfaces. At the beginning $\mathrm{MgZn}_{2}$ phase corrodes first.

With higher passivation layer thickness the persistence against white rust in salt spray test does increase. However, the persistence against red rust decreases. This may be caused by localization of the corrosion attack. Electrochemical studies show that the stability of the chemically passivated surface is not only a function of the number of pores in the conversion layer, but also a function of the $\mathrm{pH}$-value of the electrolyte. Conversion coatings on $\mathrm{ZM}$ in comparison to $\mathrm{Z}$ emulsion can behave better regarding $\mathrm{pH}$ stability. So far all tested $\mathrm{Cr}$-free passivation systems on phosphate or polycarboxylate-base show a significant higher corrosion persistence on ZM in comparison than on the $\mathrm{Z}$ surface. The mechanism for this behavior is not fully understood. Therefore further studies are needed.

\section{ACKNOWLEDGMENTS}

The financial support by the CEST (Competence centre for electrochemical surface technology) is gratefully acknowledged. The technical support by the long time project partners e.g. Henkel ${ }^{\circledR}$ and BASF® is also gratefully acknowledged. The intensive support of the stuff from voestalpine galvanizing lines is highly appreciated. The authors wish to thank everybody who contributed to the successful development.

\section{REFERENCES}

[1] S. Schuerz, G. Luckeneder, M. Fleischanderl, K.H. Stellnberger, G. Mori, NACE Corrosion 2011, Houston, Texas, USA (2011)

[2] J. Hagler, G. Angeli, D. Ebner, G. Luckeneder, M. Fleischanderl, M. Schatzl, New Zinc-Magnesium-Alloy Coatings for Building and Construction, Proceedings of the Eurosteel, Graz, Austria (2008)

[3] 2002/95/EC restriction on use of hazardous substanzes (RoHS Restriction)

[4] 2000/53/EC end of life vehicle directive [http://europa.euint/eurlex/de/lif/]

[5] J. De. Strycker, F. Hörzenberger, T. Meert, Cr-free thin coatings on galvanised steel sheet, Galvatech, USA (2004)

[6] M. Fleischanderl, What does the Restriction of Hazardous Substances (RoHS) entail?, International Appliance Manufacturing (2005), 30-34

[7] F.M. Androsch and M. Fleischanderl, Substitution of Cr(VI)-Treatments at voestalpine - Strategy, Implementation and Experience, Galvanized Steel Sheet Forum, Germany (2006)

[8] Applied for a patent

[9] S. Schuerz, M. Fleischanderl, G. Luckeneder, K. Preis, T. Haunschmied, G. Mori, A.C. Kneissl, Corrosion Science 51 (2009), 2355-2363

[10] S. Schuerz, G. Luckeneder, M. Fleischanderl, P. Mack, H. Gsaller, A.C. Kneissl, G. Mori, Corrosion Science 52 (2010), 32713279

[11] W. Bertkau, M. Essig, A. Göthlich, M. Herrlich-Loos, H. Witteler, G. X. Showalter, K. Matsuoka, Temporary corrosion protection of galvanized steel - a new, fluoride-free and heavy metal-free technology, Galvatech, Japan (2007)

[12] G. Reiter, M. Fleischanderl, C. Commenda, G. Fafilek, Corrosion Restriction of Chromium-free Conversion Layers on hot tip galvanized steel, Corrosion (2010)

[13] M. Fleischanderl, Dissertation, TU Vienna (2007)

[14] J.W. Schultze and N. Muller, Qualitätskontrolle von Phosphatschichten, Metalloberfläche, 531 (1999) 17-22.

Abstract
Sviluppo di trattamenti sottili multifunzionali esenti da cromo
per acciai zincati a caldo per immersione: strategia, attuazione ed esperienza
Parole chiave: rivestimenti, acciaio
$\begin{aligned} & \text { Poiché l'utilizzo di cromo esavalente nelle apparecchiature automobilistiche ed elettroniche è in gran parte vietato, sono stati svi- } \\ & \text { luppati diversi strati di conversione senza cromo esavalente. In questo lavoro sono stati caratterizzati (mediante microscopia } \\ & \text { elettronica e altri metodi di analisi delle superfici) diversi rivestimenti di conversione esenti da Cr a base di fosfato e policar- } \\ & \text { bossilato per l'impiego di uno strato dalle caratteristiche multifunzionali per nastri di acciaio zincati per immersione a caldo. Un } \\ & \text { altro argomento di questo studio [2] riguarda la resistenza alla corrosione dei diversi rivestimenti di conversione quali ZM [1] } \\ & \text { (ZnAlMg) e Z (Zn). Le proprietà di protezione dalla corrosione di questi rivestimenti di conversione a base di fosfato su Z e ZM } \\ & \text { sono stati caratterizzati mediante una prova standardizzata in nebbia salina. Infine sono stati studiati, mediante voltammetria } \\ & \text { ciclica, l'effetto degli strati di conversione e della barriera protettiva su zinco e zinco magnesio trattati esenti da Cr. }\end{aligned}$

